\title{
ASSESSMENT OF KNOWLEDGE, ATTITUDE AND PRACTICES ABOUT NUTRITIONAL SUPPLEMENTS OF THE STAFF AND STUDENTS OF UNIVERSITI KUALA LUMPUR - ROYAL COLLEGE OF MEDICINE PERAK MALAYSIA
}

ATM Emdadul Haque1, Muhamad Noor Azalizam Bin Abdullah2, Nurul Syahirah Binti AB Rahman³, Shanna Asyeqeen Binti Adzman', Wan Hanim Aqilah Binti Wan Suhaimi ${ }^{5}$, Mainul Haque 6

\author{
${ }^{1}$ Associate Professor \& HOD, Department of Medical Education, Universiti Kuala Lumpur Royal College of Medicine Perak \\ (UniKL RCMP), Malaysia. \\ ${ }^{2} 2^{\text {nd }}$ Year Medical Student, UniKL RCMP, Malaysia. \\ ${ }^{3} 2^{\text {nd }}$ Year Medical Student, UniKL RCMP, Malaysia. \\ ${ }^{4} 2^{\text {nd }}$ Year Medical Student, UniKL RCMP, Malaysia. \\ 52nd Year Medical Student, UniKL RCMP, Malaysia. \\ ${ }^{6}$ Professor, Department of Pharmacology, Faculty of Medicine and Defense Health, National Defense University of Malaysia, \\ Kem Sungai Besi, Kuala Lumpur, Malaysia.
}

\section{ABSTRACT}

\section{BACKGROUND}

The rate of usage of nutritional supplement has increased tremendously over the past decades. In Malaysia, the dietary supplement market is about US $\$ 17.30 /$ month.

\section{AIM}

The aim of this study was to determine the association of knowledge, attitude and practice about nutritional supplements with socio-demographic factors of the respondents.

\section{METHODS}

This was a cross-sectional study, conducted in 2015 at UniKL-RCMP, Malaysia. Convenient sampling was used. The data extracted from the questionnaires, entered into the Microsoft Excel and were analysed by using the SPSS version 17.

\section{RESULTS}

Only $43.1 \%$ respondents were graded as good knowledge level on nutritional supplement, while the majority (56.9\%) respondents had a poor knowledge level. The knowledge on nutritional supplement were attained by majority from friends/families, doctors/pharmacists, television, articles, newspaper, reading books, radio and journal. The majority of study respondents was having a good healthy lifestyle. Most of the staff and students were non-smokers (99\%), non-alcoholic (98\%), supplement users (50.8\%) and do regular exercise (85.8\%). The correlation between Knowledge, Attitude and Practice (KAP) of nutritional supplements with gender, occupation and marital status were statistically significant.

\section{CONCLUSION}

This study shows that majority of nutritional supplement users were female, and also demonstrated that the participants had poor knowledge regarding nutritional supplement especially regarding cost, adverse reactions and evidence-based health benefit.

\section{KEYWORDS}

Nutritional Supplements, Staff and Students, UniKL RCMP, Malaysia.

HOW TO CITE THIS ARTICLE: Haque ATME, Abdullah MNAB, Rahman NSBAB, et al. Assessment of knowledge, attitude and practices about nutritional supplements of the staff and students of Universiti Kuala Lumpur - Royal College of Medicine Perak, Malaysia. J. Evolution Med. Dent. Sci. 2016;5(67):4815-4820, DOI: 10.14260/jemds/2016/1097

\section{INTRODUCTION}

'Nutritional Supplements (NS) include vitamins, minerals, herbs, meal supplements, sports nutrition products, natural food supplements and other related products used to boost the nutritional content of the diet.'(1)

Financial or Other, Competing Interest: None.

Submission 03-07-2016, Peer Review 08-08-2016,

Acceptance 13-08-2016, Published 22-08-2016.

Corresponding Author:

ATM Emdadul Haque,

Associate Professor \& Head,

Medical Education Department,

Universiti Kuala Lumpur Royal College of Medicine,

Perak (UniKL RCMP), Malaysia.

E-mail: emdadul@unikl.edu.my

DOI: $10.14260 /$ jemds/2016/1097
US Food and Drug Administration defines NS as 'a dietary supplement or product intended for ingestion that contains a "dietary ingredient" intended to add further nutritional value to (Supplement) the diet.' NS are defined as concentrated sources of nutrients or other substances with a nutritional or physiological effect that supplement the normal diet.(2) Currently, dietary supplements are used in both developing and developed countries. The nutrition and supplements market size was of US $\$ 96$ billion in 2012 and was expected to rise approximately US $\$ 104$ billion globally.(3) Malaysians spent an average of US $\$ 17.30$ per month on NS; actually Malaysian people also consumes other health foods enriched with supplements which was estimated to be worth of US $\$ 526$ million.(4,5) Malaysian over-the-counter healthcare would show moderate growth by $18 \%$ to reach RM1, 283 million by 2008.6,7) 'In Malaysia, there is no specific definition of a food 
supplement in Malaysia.(8) Dietary and nutritional supplement products have been considered by health authorities as being part of health supplement products are regulated as pharmaceutical products in Malaysia by the Drug Control Authority (DCA).(9)

The Economist reported that with the uncertain and ambiguous expectation, Americans take health and NS costing over US $\$ 25$ billion.(10) Supplementary antioxidants, folic acid and $B$ vitamins and multivitamin and mineral supplements do not have enough evidences to protect and prevent mortality or morbidity due to major chronic diseases. Multiple research group believe that supplementing the diet of well-nourished adults has no clear benefit and might even be harmful and should not be used for prevention of chronic diseases.(11-13) Lot of research has been conducted on NS in developed countries and still ongoing. However, there are limited research conducted on NS in Malaysia. Therefore, the current study goals were to identify the awareness regarding dietary supplements among the students and staffs of UniKL RCMP.

\section{METHOD AND MATERIALS}

This was a cross-sectional descriptive study which was carried out in the UniKL Royal College of Medicine Perak, Ipoh, Malaysia. Students and staff from both 'Faculty of Medicine (FOM)' and 'Faculty of Pharmacy and Health Sciences (FPHS)' were included. The total study period of our research was about 10 weeks from November 2015 to January 2016. Ethical approval was obtained from the Ethical Committee before the data collection was started. The data collection, data cleaning, data entry, data analysis and report writing were carried out step by step. Using Epi Info 7 (StatCalc utility) with an expected frequency of $50 \%$ and confidence limits of $10 \%$, minimum sample size was calculated (92) in 95\% confidence level.

Structured questionnaires were prepared and distributed randomly using convenient sampling to the target population. Participants were required to fill out the consent form before completing the questionnaire. The questionnaire consisted of three sections: Section A: Demographic information. This included the respondent's age, gender, ethnicity, occupation, marital status, level of education, monthly family income, height and weight. Section B: Knowledge about nutritional supplement. In this section, the respondents were asked about their opinions regarding the statements and answered using the Likert-type scale. Section C: Practices and attitudes on nutritional supplement. Items asked in this section were about the lifestyle, frequency of nutritional supplement use, source of information, type of supplement and reasons taking supplements. The formation of questions for the questionnaire was based on a previous study.(14,15) After collection of the completed questionnaire, the data were entered in the Microsoft Excel and was analysed by using the SPSS version 21 and all associations were tested by using Chi square test.

\section{RESULTS}

A total of 197 students and staffs of UniKL RCMP participated in the study. The majority of the respondents were from the age group of below 25 years $(90.9 \%, 179)$, females $(71.06 \%$, $140)$, Malays $(89.8 \%, 177)$, single $(91.4 \%, 180)$, medical students $(71.6 \%, 141)$, obtained education up to degree (90.9\%, 179), a total family income of more than Malaysian Ringgit RM 5001/- $(50.8 \%, 100)$ and BMI $(62.4 \%, 123)$ (Table 1). The bulk (88\%) of nutritional supplement users was from age below 25 years. Furthermore, most of nutritional supplement users were female (73.0\%). The use of nutritional supplement among the Malays were highest (92.0\%). Among the respondents, medical students were found to use most of the nutritional supplement (67.0\%). The participants who are single $(88.0 \%)$ were the highest users of NS than married individuals. Likewise, the majority $(86.0 \%)$ of nutritional supplement users were degree holders and the majority (49.0\%) had monthly family income of RM5, 001.00. The majority $(60.0 \%)$ nutritional supplement users had normal BMI (Table 2). All of our study respondents have heard about NS and they received information either from friends/families (21\%), doctors/pharmacists (15\%), television (15\%), reading articles (14\%), newspaper (13\%), reading books (11\%), radio (5\%), journal (4\%); 85 (43.1\%) respondents have been graded as having good knowledge and the rest $112(56.9 \%)$ have poor knowledge regarding NS. Among our study population, 85 (43.1\%) and 112 (56.9\%) had good and poor knowledge level respectively on NS unrelatedly whether they were users or non-users.

Regarding lifestyle practices among study participants, the majority of them was having a good healthy lifestyle. Most of the staff and students were non-smokers (99.0\%), nonalcoholic (98.0\%) and nutrition supplement users (50.8\%). The study participants do exercise at least once a week (36.0\%), twice a week (18.3\%), three times per week (17.8\%) and everyday (13.7\%) respectively. The most used types of NS are vitamins $(62 \%)$ followed by minerals $(13 \%)$, herbal products $(10 \%)$, a protein supplement (8\%), sports nutrition (3.0\%), meal supplement (2\%) and others (2\%) (Figure 1). Other types of supplements used were honey and hormonal supplement. NS are consumed commonly to maintain good health (49.3\%), adequate nutrition (26.3\%), physical appearance $(15.6 \%)$, to lose weight $(5.3 \%)$ and others $(2 \%)$. Other reasons to take supplements were to gain weight and mother's advice. Most of the nutritional supplement users were consuming the supplements daily (30.5\%) followed by occasional $(22.0 \%)$, weekly $(8.1 \%)$ and monthly $(1.0 \%)$. The majority of the users $(91 \%)$ felt better, while $9 \%$ did not feel any improvement; $81 \%$ of the users consuming the supplement without any doctor's prescription, while rest $19.0 \%$ of them consume with the advice of doctors.

The majority of the users who showed good knowledge about nutritional supplement had good attitudes towards it (58.1\%) too. On the other hand, users that have poor knowledge about supplement have poor attitude towards it $(49.1 \%)$. There were no statistically significant $(p=0.422)$ relation found between knowledge and attitude. Respondents with good knowledge and good attitude towards nutritional supplement has a higher percentage of using the nutritional supplement (55.6\%) compared to respondents who have poor knowledge with a poor attitude (48.3\%). There was no statistically significant $(\mathrm{p}=0.245)$ association found between knowledge and attitude to practice when compared between nutritional supplement users and non-users. The majority of participants who have good KAP were from the age group more than 45 years $(80.0 \%)$, while the least was from the age group less than 25 years (44.1\%). The majority of participants who have poor KAP are from the age group less than 25 years (55.9\%), while the least was from the age group more than 45 years $(20.0 \%)$. Nonetheless, there was no statistically significant $(p=0.266)$ association found between KAP when 
compared between supplement users among the different age groups.

The majority of participants who have good KAP were male (61.4\%) followed by female (40.0\%), while poor KAP was mostly from female $(60.0 \%)$. Yet, there was statistically significant $(p=0.006)$ association found between KAP and gender among NS users (Figure 2). On the other hand, there was no statistically significant $(p=0.761)$ association found between KAP and ethnic distribution. However, there was statistically significant $(p=0.002)$ association found between KAP and occupation of the users (Figure 3). The majority of participants who have good KAP were married group (70.6\%), whereas the poor KAP were from the single group (56.1\%). However, there was statistically significant $(p=0.035)$ association found between KAP and marital status of the NS users (Figure 4).

Based on educational background, good KAP were found among the SPM level and PhD level (100\%) and the poor KAP were from the degree level (56.4\%), master level (50.0\%) and the diploma level (42.9\%). On the other hand, there was no statistically significant $(\mathrm{p}=0.061)$ association found between KAP and education level among the NS users. The majority of participants who have good KAP were overweight (54.3\%), obese (46.7\%) and the least among the underweight (37.5\%). The majority of participants who have poor KAP were underweight $(62.5 \%)$ followed by the participants that have normal BMI status (54.5\%) and the lawsuit by participants that are overweight $(45.7 \%)$. The participants who are overweight based on BMI status had a higher percentage of good KAP compared to normal BMI status participants, but underweight participants had a lower percentage of having good KAP compared to normal BMI participants. Yet there was no statistically significant $(p=0.642)$ association found between KAP and BMI status of the NS users.

\begin{tabular}{|c|c|c|c|}
\hline \multicolumn{2}{|c|}{ Variables } & $\mathbf{N}$ & $\%$ \\
\hline \multirow{4}{*}{ Age } & $<25$ & 179 & 90.9 \\
\hline & $25-34$ & 11 & 5.6 \\
\hline & $35-44$ & 2 & 1.0 \\
\hline & $>45$ & 5 & 2.5 \\
\hline \multirow{2}{*}{ Gender } & Male & 57 & 28.9 \\
\hline & Female & 140 & 71.1 \\
\hline \multirow{4}{*}{ Ethnicity } & Malay & 177 & 89.9 \\
\hline & Indian & 10 & 5.1 \\
\hline & Chinese & 3 & 1.5 \\
\hline & Others & 7 & 3.6 \\
\hline \multirow{4}{*}{ Occupation } & $\begin{array}{l}\text { Medical } \\
\text { Students }\end{array}$ & 141 & 71.6 \\
\hline & Staffs & 11 & 5.6 \\
\hline & $\begin{array}{c}\text { Pharmacy } \\
\text { Students }\end{array}$ & 38 & 19.3 \\
\hline & Lecturers & 7 & 3.6 \\
\hline \multirow{4}{*}{ Marital Status } & Single & 180 & 91.4 \\
\hline & Married & 17 & 8.6 \\
\hline & Divorced & - & - \\
\hline & Widow & - & - \\
\hline \multirow{5}{*}{$\begin{array}{c}\text { Level of } \\
\text { Education }\end{array}$} & SPM & 4 & 2.0 \\
\hline & Diploma & 7 & 3.6 \\
\hline & Degree & 179 & 90.9 \\
\hline & Master & 4 & 2.0 \\
\hline & $\mathrm{PhD}$ & 3 & 1.5 \\
\hline Monthly & $<$ RM 1000 & 18 & 9.1 \\
\hline
\end{tabular}

\begin{tabular}{|c|c|c|c|}
\hline Family Income & RM 1001-RM 3000 & 38 & 19.3 \\
\cline { 2 - 4 } & RM 3001-RM 5000 & 41 & 20.8 \\
\cline { 2 - 4 } & $>$ RM 5001 & 100 & 50.8 \\
\hline \multirow{3}{*}{ BMI } & Underweight & 24 & 12.2 \\
\cline { 2 - 4 } & Normal & 123 & 62.4 \\
\cline { 2 - 4 } & Overweight & 24 & 12.2 \\
\cline { 2 - 4 } & Obese & 15 & 7.6 \\
\hline
\end{tabular}

Table 1: Respondents' Demographic Information

\begin{tabular}{|c|c|c|c|}
\hline \multicolumn{2}{|c|}{ Variables } & $\mathrm{N}=100$ & $\%$ \\
\hline \multirow{4}{*}{ Age } & $<25$ Years & 88 & 88.0 \\
\hline & 25-34 Years & 6 & 6.0 \\
\hline & 35-44 Years & 2 & 2.0 \\
\hline & $>45$ Years & 4 & 4.0 \\
\hline \multirow{2}{*}{ Gender } & Male & 27 & 27.0 \\
\hline & Female & 73 & 73.0 \\
\hline \multirow{4}{*}{ Ethnicity } & Malay & 92 & 92.0 \\
\hline & Indian & 4 & 4.0 \\
\hline & Chinese & 2 & 2.0 \\
\hline & Others & 2 & 2.0 \\
\hline \multirow{4}{*}{ Occupation } & Medical Students & 67 & 67.0 \\
\hline & Pharmacy Students & 8 & 8.0 \\
\hline & Staff & 21 & 21.0 \\
\hline & Lecturer & 4 & 4.0 \\
\hline \multirow{4}{*}{ Marital Status } & Single & 88 & 88.0 \\
\hline & Married & 12 & 12.0 \\
\hline & Divorced & 0 & - \\
\hline & Widow & 0 & - \\
\hline \multirow{5}{*}{$\begin{array}{l}\text { Level of } \\
\text { Education }\end{array}$} & SPM & 3 & 3.0 \\
\hline & Diploma & 6 & 6.0 \\
\hline & Degree & 86 & 86.0 \\
\hline & Master & 3 & 3.0 \\
\hline & PhD & 2 & 2.0 \\
\hline \multirow{4}{*}{$\begin{array}{c}\text { Monthly Family } \\
\text { Income (RM) }\end{array}$} & $<1000$ & 5 & 5.0 \\
\hline & $1001-3000$ & 19 & 19.0 \\
\hline & $3001-5000$ & 27 & 27.0 \\
\hline & $>5001$ & 49 & 49.0 \\
\hline \multirow{4}{*}{ BMI } & Underweight & 14 & 14.0 \\
\hline & Normal & 60 & 60.0 \\
\hline & Overweight & 17 & 17.0 \\
\hline & Obese & 9 & 9.0 \\
\hline $\begin{array}{r}\text { Table } 2 \\
\text { Nut }\end{array}$ & $\begin{array}{l}\text { emographic Inforr } \\
\text { onal Supplements }\end{array}$ & $\begin{array}{l}\text { on of } \\
\text { rs }\end{array}$ & \\
\hline
\end{tabular}

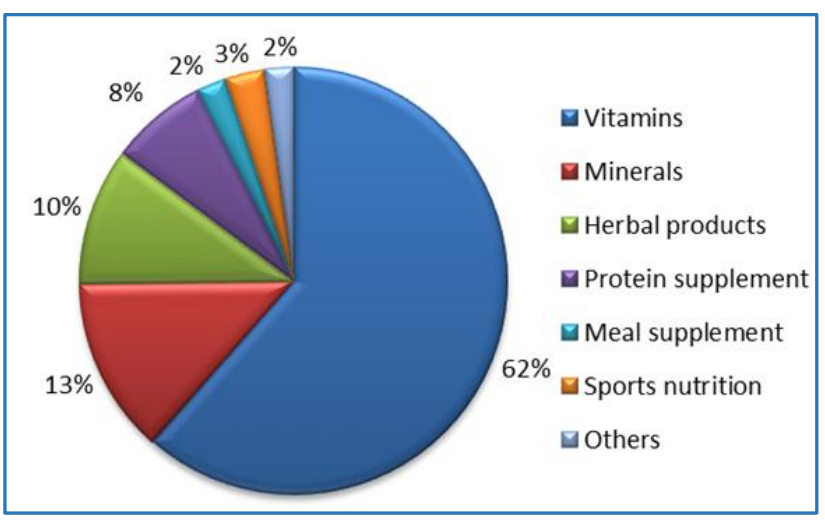

Fig. 1: Type of Nutritional Supplements that being Consumed by the Respondents 


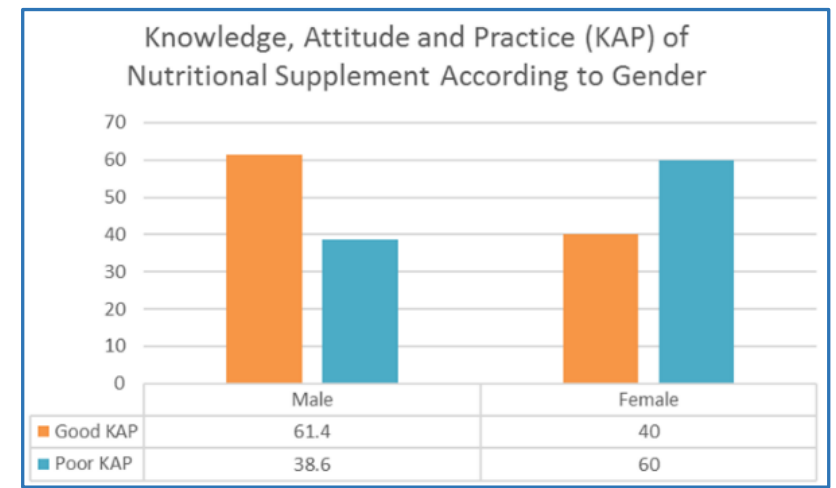

Fig. 2: Correlation between KAP of Nutritional Supplements According to Sex $(p=0.006)$

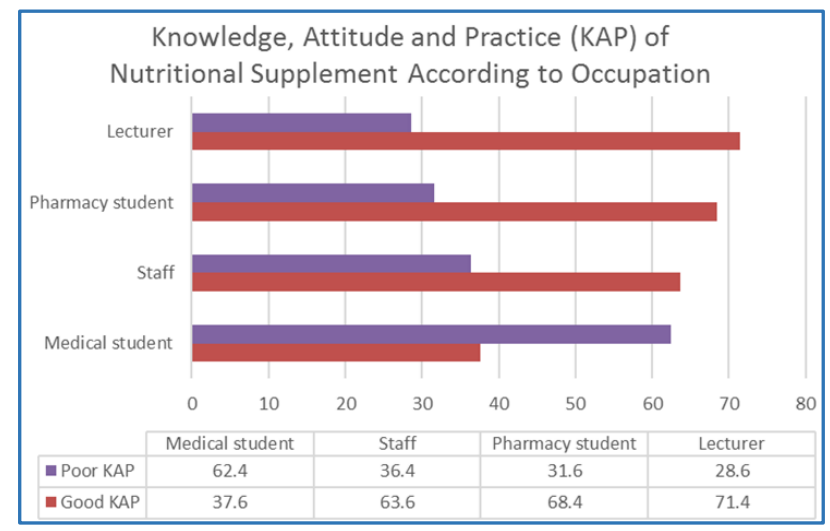

Fig. 3: Correlation KAP of Nutritional Supplement According to Occupation ( $p=0.002$ )

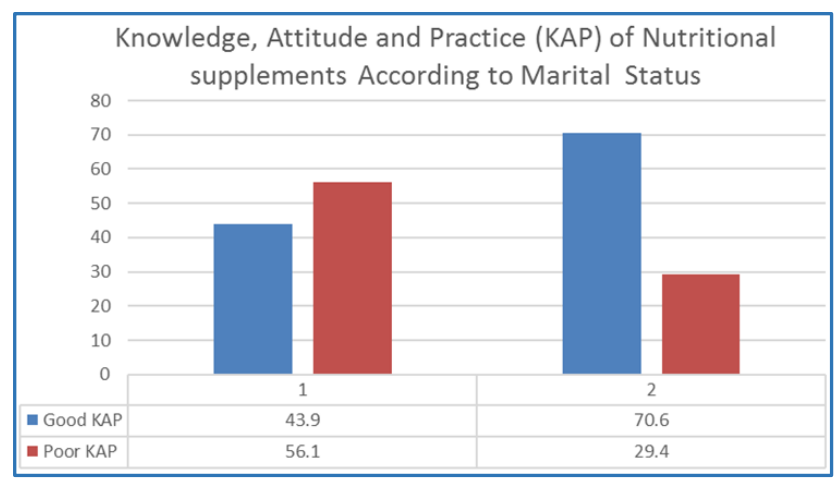

Fig. 4: Correlation KAP of Nutritional Supplements According to Marital Status ( $p=0.035)$

\section{DISCUSSION}

The majority (56.9\%) of current study respondents possess poor knowledge regarding NS. The alike research from Nigeria revealed that their mainstream study population poses a good level of knowledge. Therefore, present study findings were quite dissimilar with that of Nigeria.(16) The existing results can be interpreted as the study cohort comprises of different group of people, which may affect the result. The difference can be explained, as Nigerian study population was only medical students. Almost two-thirds of the students said dietary supplement can be used as substitute of natural nutrients derived from foods, indicates some knowledge deficiency because dietary supplements are supposed to supplement and not substitute natural nutrients from food. This study also indicates the student's lack of full and precise knowledge about dietary supplements because dietary supplements do have side-effects. Therefore, the current study findings were similar with study conducted in modern world.(17) The current findings can be explained as NS has so much of belligerent persuasive events within the community; therefore, study participants may be much influenced of such unreasonable publicity. NS users of the present study participants, $91 \%$ believed that the chosen type of NS was effective. Multiple studies were also similarly reported that NS consumers have a preconceived impression that these substances are effective in improving health, which is similar with the current findings. ${ }^{(18,19)}$ NS can be grouped into four basic categories: sport foods, dietary supplements, ergogenic aids and herbs/traditional products. $(20,21)$

But our study respondents considered are vitamins followed by mineral, herbal products, protein supplement, sports nutrition, meal supplement and others. The differences in categorising NS may be due to different nationality, sociocultural environment. The current study participants majority consumed vitamins as NS, which is similar to the study of the use of dietary supplements among professional athletes in Saudi Arabia.(22) The current findings also can be explained as it has become a popular belief in many countries including Malaysia that vitamin supplementation maintains health and energy level. Although, there are growing evidences that such indiscriminate use of vitamins and micronutrients cause no health benefits over balanced diet, but only increase wastage of money and adverse reactions.(23) Friends' and family's influence play the most important role as the source of information about NS by the staffs and students in this study. This finding is quite similar to that observed that peer influences have a positive relationship with the NS usage. (24)

Among the current study participants, the majority of NS users were below 25 years old. This may be due to the majority of the study participants were of same age group as the study was conducted among University students and staff. The current study findings were totally different from other studies from foreign countries.(25,26) Nevertheless, these studies $(25,26)$ from both sides of Atlantic reported that older age group were main consumers of NS. The present was conducted in an University among students and staffs, but mentioned two studies $(25,26)$ were conducted in community. Therefore, study results were different. On the other hand, two more studies conducted in Asia and North America among Medical Students and Intern reported that they had moderate-to-high tendency to consume NS. $(27,28)$

Yet again among NS users of this study, women were the majority. But women were also comprising greater part of the study population. Women in this study were much higher in number than male colleagues. Therefore, there were no similarities between the number of study participants in considering sexes, which may have been an influence because of disproportionate distribution of study participants in considering sex. Among current study participants, females guzzles statistically significantly $(\mathrm{p}=0.006)$ higher than their male counterpart. Earlier two analogous studies also conveyed that ladies consume higher amongst NS than males. ${ }^{(14,29)}$ Similarly, Saudi Arabian womankind ingests NS statistically significantly $(\mathrm{p}<0.001)$ higher than men.(30) Therefore, there is an urgent need to study further the reasons for these findings and also with a large sample size and in heterogeneous population. 


\section{CONCLUSION}

This study also demonstrates that the participants have a poor knowledge regarding nutritional supplement. Most of them do not know that NS also can cause adverse reaction and there is no definite evidence for any health benefit. More research is advocated to promote more judicial use of NS among Malaysian population.

\section{LIMITATIONS}

This is a cross-sectional study with its own inherent limitation. Furthermore, the small sample size may not be actually representing the entire population of Malaysia.

\section{ACKNOWLEDGEMENT}

Authors are much grateful to those study participants who spare their valuable time to give input of the current study. We are also grateful to UniKL-RCMP authority for their kind cooperation. Lastly, we would like to extend our gratitude to the Ethical Committee of UniKL-RCMP for the approval of the study.

\section{REFERENCES}

1. The free dictionary. By Farlex. http://medicaldictionary.thefreedictionary.com/Nutritio nal+Supplements

2. US Food and drug administration. What is a dietary supplement? 10903 New Hampshire Avenue, Silver Spring, MD 20993. 2015.

http://www.fda.gov/AboutFDA/Transparency/Basics/u cm195635.htm

3. Globe Newswire. Global nutrition and supplements market: history, industry growth and future trends by PMR. New York, 2015.

https://globenewswire.com/newsrelease/2015/01/27/700276/10117198/en/GlobalNutrition-and-Supplements-Market-History-IndustryGrowth-and-Future-Trends-by-PMR.html

4. UK Essays. Effect of dietary supplements on students academic performance health essay. 2013. https://www.ukessays.com/essays/health/effect-ofdietary-supplements-on-students-academicperformance-health-essay.php?cref

5. Ahma N. Nutritional supplements, nutraceutical, herbal medicines. 2002.

http://strategis.ic.gc.ca/epic/internet/inimrri.nsf/en/gr111702e.html

6. Euromonitor. OTC Healthcare in Malaysia. 2004. http://www.euromonitor.com/OTC_Healthcare_in_Mala ysia

7. US Food and Drug Administration. Dietary supplements. 10903 New Hampshire Avenue, Silver Spring, MD 20993. 2015.

http://www.fda.gov/Food/DietarySupplements/

8. Lex Mundi. Differences and similarities in food supplement regulations, Malaysia. The world's leading association of independent law firms. Houston, Texas 77027, USA.

file://C:/Users/Mainul\%20Haque/Downloads/GPG_FS R_LS_Malaysia\%20(2).pdf

9. National pharmaceutical control bureau. Ministry of Health Malaysia.

http://bpfk.moh.gov.my/images/Guidelines_Central/Gui delines_on_Regulatory/Guidance_on_Classification_oct20 11.pdf
10. The economist. The economist explains why NS may not be useful. 2015

http://www.economist.com/blogs/economistexplains/2 015/09/economist-explains-13

11. Fortmann SP, Burda BU, Senger CA, et al. Vitamin and mineral supplements in the primary prevention of cardiovascular disease and cancer: an updated systematic evidence review for the U.S. preventive services task force. Ann Intern Med 2013;159(12):824-34.

12. Grodstein F, O'Brien J, Kang JH, et al. Long-term multivitamin supplementation and cognitive function in men. A randomized trial. Ann Intern Med 2013;159(12):806-14.

13. Lin JS, O'Connor E, Rossom RC, et al. Screening for cognitive impairment in older adults: a systematic review for the U.S. preventive services task force. Ann Intern Med 2013;159(9):601-12.

14. Al-Naggar RA, Chen R. Prevalence of vitamin-mineral supplements use and associated factors among young Malaysians. Asian Pac J Cancer Prev 2011;12(4):1023-9.

15. Owens C, Baergen R, Puckett D. Online sources of herbal product information. Am J Med 2014;127(2):109-15.

16. Aina BA, Ojedokun OA. Knowledge and use of dietary supplements by students of college of medicine, University of Lagos, Idi-Araba, Lagos, Nigeria. J Basic Clin Pharm 2014;5(2):34-9.

17. McDowall JA. Supplement use by young athletes. J Sports Sci Med 2007;6(3):337-42.

18. Tian HH, Ong WS, Tan CL. Nutritional supplement use among university athletes in Singapore. Singapore Med J 2009;50(2):165-72.

19. Dunford M. Fundamentals of sport and exercise nutrition. Human kinetics. 2010.

20. Butterfield G. Ergogenic aids: evaluating sport nutrition products. Int J Sport Nutr 1996;6(2):191-7.

21. Bucci LR. Selected herbals and human exercise performance. Am J Clin Nutr 2000;72(2):624S-36S.

22. Aljaloud SO, Ibrahim SA. Use of dietary supplements among professional athletes in Saudi Arabia. J Nutr Metabolism Article ID 245349, 2013;2013:1-7.

23. Harvard medical school. Food and vitamins and supplements! oh my! demystifying nutrition: the value of food, vitamins and supplements. The Joseph B. Martin conference center, Harvard Medical School, 77 Avenue Louis Pasteur, Boston, MA 02115. 2013. https://hms.harvard.edu/sites/default/files/assets/Site s/Longwood_Seminars/Nutrition_3_5_13.pdf

24. Suraya HS, Azmawati MN. Use of non-prescription substances among University students in Malaysia. Malaysian J Public Health Med 2014;14(2):86-98.

25. Lyle BJ, Mares-Perlman JA, Klein BE, et al. Supplement users differ from non-users in demographic, lifestyle, dietary and health characteristics. J Nutr 1998;128(12):2355-62.

26. Knudsen VK, Rasmussen LB, Haraldsdóttir J, et al. Use of dietary supplements in Denmark is associated with health and former smoking. Public Health Nutr 2002;5(3):463-8.

27. Spencer EH, Bendich A, Frank E. Vitamin and mineral supplement use among US medical students: a longitudinal study. J Am Diet Assoc 2006;106(12):197583. 
28. Sotoudeh G, Kabiri S, Yeganeh HS, et al. Predictors of dietary supplement usage among medical interns of Tehran University of Medical Sciences. J Health Popul Nutr 2015;33(1):68-75.

29. Ghazali E, Mutum D, Lee LL. Dietary supplements users vs non-users in Malaysia: profile comparisons for marketing purposes. In: Welsh DHB. ed. Proceedings of AGBA 3rd world congress, advanced in global business research. Kuala Lumpur, Malaysia 2006:43-54.
30. Al-Faris EA, Al-Rowais N, Mohamed AG, et al. Prevalence and pattern of alternative medicine use: the results of a household survey. Ann Saudi Med 2008;28(1):4-10. 